\title{
Saccharin ingestion, weight loss, and mortality in rats*
}

\author{
ALFRED VOLO and ANDREW STROUTHES \\ State University of New York at Binghamton, Binghamton, New York 13901
}

\begin{abstract}
Rats maintained on $10 \mathrm{~g}$ of food and saccharin solutions suffered weight loss and mortality compared with controls maintained on $10 \mathrm{~g}$ food and water. Frequency of death was related to amount and concentration of the ingested solution, while weight loss was related only to concentration and absolute amount of saccharin intake.
\end{abstract}

Sodium saccharin $\left(\mathrm{C}_{7} \mathrm{H}_{4} \mathrm{NNaO}_{3} \mathrm{~S} \cdot 2 \mathrm{H}_{2} \mathrm{O}\right)$ is a sweet-tasting nonnutritive substance widely used by dieters as a noncaloric sweetener and by diabetics as a sugar substitute. Commercially available saccharin is buffered with an equal amount of sodium bicarbonate $\left(\mathrm{NaHCO}_{3}\right)$. In this and previous studies (Strouthes, 1970, 1971, 1973), the term saccharin refers to such a mixture.

At relatively low concentrations, saccharin is preferred by laboratory rats and it has been used as a reinforcer in animal studies partly because of its freedom from the postingestional effects which follow the consumption of nutritive reinforcers such as food or sucrose solutions.

The physiological action of saccharin has, however, been the subject of investigation for over 60 years. Early experimenters (Folin, 1914; Herter, 1910) found saccharin to be physiologically inert, i.e., it was excreted in the urine unchanged. Large doses, however, were found to cause headaches, gastrointestinal disturbance, and cardiac depression in humans. Carlson, Eldridge, Martin, and Foran (1923) found that saccharin ingestion by humans resulted in (a) slowing of peptic digestion, (b) secretion of gastric juice (when placed on the tongue), (c) increased acidity of gastric juice, (d) delayed absorption of water in the small intestine, and (e) a marked temporary depression of kidney function. Other effects attributed to or suspected of saccharin include an inhibitory effect on urine output, followed by increased urine flow (Haramaki, 1948), decrease in resting blood sugar level (Bunde \& Lackey, 1948; Kun \& Istvan, 1947), a diuretic effect (Beebe-Center, Black, Hoffman, $\&$ Wade, 1948), potentiation of insulin coma (Valenstein \& Weber, 1965), a nutritive effect of the $\mathrm{Na}+$ ion (Valenstein, 1966; Warren \& Warren, 1966), and increased incidence of bladder carcinomas when surgically implanted in the bladders of mice (Bryan, Erturk, \& Yoshida, 1970).

Recent studies by Strouthes $(1970,1971,1973)$ have

*This research was carried out by the first author as part of a masters thesis under the supervision of the second author. Thanks are extended to John L. Fuller and Richard G. Burright, members of the committee. Parts of this paper were read at the 43rd annual meeting of the Eastern Psychological Association, Boston, April 1972. For reprints write to A. Strouthes, Department of Psychology, State University of New York at Bingham ton, Binghamton, New York 13901. indicated that the postingestional effects of saccharin must be taken into account when the substance is used in behavioral studies. Specifically, Strouthes (1970) found that rats on a reduced food schedule $(10 \mathrm{~g}$ per day) with ad lib access to varied concentrations of saccharin solutions drank great quantities of these liquids, and came to weigh less than control groups that received the same amount of food and deionized water. In addition, death occurred in a significant proportion of the saccharin animals, while control animals did not die. For example, each of the three groups of five rats were given $0.1 \%, 1.0 \%$, or $2.0 \%$ saccharin solution. They ingested, respectively, an average of 65,96 , and $80 \mathrm{ml}$ daily, and, after 48 days, had mean body weights of 189 , 185 , and $178 \mathrm{~g}$, with 1,3 , and 5 deaths occurring. An identical control group ingested an average of $22.5 \mathrm{ml}$ of water per day, had a mean weight of $196 \mathrm{~g}$, and suffered no deaths.

In the above study, saccharin concentration was inherently confounded with amount of liquid intake. It is uncertain, therefore, whether the observed weight loss and mortality were due primarily to saccharin consumption or to the unusually large volume of liquid drunk by saccharin groups. The present study was conducted to determine more precisely how saccharin concentration and amount of liquid intake affect weight loss and mortality among rats on a reduced food schedule.

\section{METHOD}

\section{Subjects}

Ss were 52 90-day-old naive male Sprague-Dawley albino rats, weighing from 265 to $309 \mathrm{~g}$ at the start of the experiment. Rats were individually hou sed in cages in an air-conditioned vivarium $\left(21^{\circ} \pm 2^{\circ} \mathrm{C}\right)$, which was illuminated from $6: 30$ a.m. to $6: 30$ p.m.

\section{Apparatus}

Each $25.5 \times 18 \times 19 \mathrm{~cm}$ home cage was fitted with a Kimax Richter tube of $130 \mathrm{ml}$ average capacity and a food bin. Six additional test cages were used in some phases of the experiment. These were located in a room adjacent to the vivarium and were equipped with four Davis and two Lehigh Valley Electronics (LVE) pellet dispensers, which could deliver 45-mg Noyes food pellets on command from a LVE tape reader.

Reagents were obtained from Fisher Scientific Company. All solutions were mixed by weight [ saccharin $/\left(\mathrm{H}_{2} \mathrm{O}+\right.$ saccharin $)$ ] and stored in stoppered glass jars. 
Table 1

A Chronological List of Deaths Showing Starting Weight of Rat, Weight on Day of Death, Mean Starting Weights of Groups, and Mean Weight of Surviving Group Members on Day of Death

\begin{tabular}{|c|c|c|c|c|c|}
\hline \multirow[b]{2}{*}{ Group } & \multicolumn{2}{|c|}{ Starting Weight (g) } & \multirow[b]{2}{*}{$\begin{array}{l}\text { Day of } \\
\text { Death }\end{array}$} & \multirow[b]{2}{*}{$\begin{array}{l}\text { Weight at } \\
\text { Death }(\mathrm{g})\end{array}$} & \multirow{2}{*}{$\begin{array}{c}\text { Mean } \\
\text { Weight of } \\
\text { Survivors (g) }\end{array}$} \\
\hline & $\begin{array}{l}\text { Group } \\
\text { (Mean) }\end{array}$ & Rats & & & \\
\hline $90-2$ & 231.67 & 240.00 & 10 & 173 & 199.80 \\
\hline $90-2$ & 231.67 & 240.00 & 13 & 177 & 191.25 \\
\hline $90-1$ & 233.58 & 234.50 & 15 & 156 & 187.60 \\
\hline $90-2$ & 231.67 & 236.00 & 18 & 151 & 181.33 \\
\hline $90-2$ & 231.67 & 227.00 & 24 & 126 & 179.00 \\
\hline $90-1$ & 233.58 & 235.50 & 26 & 131 & 178.33 \\
\hline $45-1$ & 234.83 & 237.50 & 33 & 140 & 167.20 \\
\hline $45-2$ & 230.50 & 237.00 & 42 & 128 & 150.75 \\
\hline $45-2$ & 230.50 & 224.50 & 48 & 138 & 152.33 \\
\hline
\end{tabular}

\section{Design and Procedures}

Rats were assigned to nine experimental groups such that mean body weights of the group were approximately equal and ranged from 285 to $286 \mathrm{~g}$. Initially, each group had six Ss. However, one rat in each of the $2 \%$ groups failed to drink saccharin of that concentration. Accordingly, two of these groups were run with five rats, while a replacement $S$ was available for the third.

There were three levels of saccharin concentration, $0 \%$ (deionized $\mathrm{H}_{2} \mathrm{O}$ ), $1 \%$ and $2 \%$, and three levels of amount of daily liquid intake, $22.5,45$, and $90 \mathrm{ml}$. The nine groups were coded by amount and concentration of daily intake; thus, a group receiving $45 \mathrm{ml}$ of $2 \%$ saccharin solution was designated $45-2$.

All three 22.5-ml groups as well as 45-1 and 45-2 were able to ingest the required amount of liquid spontaneously. They were weighed and given $10 \mathrm{~g}$ of powdered Purina Lab Chow and either 22.5 or $45 \mathrm{ml}$ of the appropriate solution at the same time each day. At this time, spillage from the previous day was measured, and an equal amount of solu tion added to the daily ration.

The remaining groups, $45-0$ and all $90-\mathrm{ml}$ groups, were required to ingest amounts of liquid which were initially greater than they would spontaneously consume. Falk's (1961) technique of producing schedule-induced polydipsia was used with these groups to insure that the required amounts of liquid were consumed. Falk demonstrated that food-deprived rats become polydipsic when placed on various food-reinforcement schedules with a tube of water available. Pilot work had shown that polydipsia could be elicited by a free variable interval $1 \mathrm{~min}$ (free VI $1 \mathrm{~min}$ ) schedule (Ferster \& Skinner, 1957) of food-pellet delivery when the available liquid was a saccharin solution. Rats were transferred to feeder-equipped cages at about the same time each day. There they received $10 \mathrm{~g}$ of $45-\mathrm{mg}$ Noyes food pellets daily on the free VI 1-min schedule. Pellets were delivered at random intervals ranging from 3 to $120 \mathrm{sec}$. At each level of fluid intake, the time required for fluid ingestion was approximately equal, whether or not the polydipsia procedure was employed. A tube containing 45 or $90 \mathrm{ml}$ of the appropriate solution was placed in each cage, and rats were removed after drinking that amount (corrected for spillage). Rats which exhausted the liquid before consuming the entire food ration were returned to their home cages, where the remaining pellets were placed into their food bins. After the first 12 days on this schedule, Groups 90-1 and 90-2 began to ingest their liquid spontaneously and thereafter were excluded from the polydipsia procedure and treated as described earlier. Since the polydipsia procedure required rats at approximately $80 \%$ of normal body weight, all rats were reduced to this level before experimental treatment began.

\section{RESULTS AND DISCUSSION}

\section{Mortality}

Deaths which occurred during the 48 days of the study are listed chronologically in Table 1 , which shows the initial weight of each rat and its weight at death. Initial mean group weights (first experimental day) and mean weight of surviving group members on the day of a death are given for comparison. In all but two cases, rats that died started out above the mean weight of their group. At the time of death, all rats weighed considerably less than the mean weight of the surviving group members. Early deaths generally occurred at higher weights than did later deaths, suggesting that rapidity of weight loss may be a more important factor than amount of weight lost. Large individual differences in susceptibility to the detrimental effect of saccharin were apparent, with those rats which lost weight least rapidly in each group surviving longest. The earliest and most frequent deaths occurred in Group 90-2. Four rats in this group died during the first 24 days of the study. No deaths occurred in any of the water groups, nor in any of the $22.5-\mathrm{ml}$ groups. Frequency of death was related to both the amount $\left(\chi^{2}=10.88, p<.005\right)$ and concentration $\left(\chi^{2}=12.03, \mathrm{p}<.005\right)$ of ingested liquid.

\section{Weight Loss}

Figure 1 shows the mean body weight of each of the nine groups for four blocks of 12 days as functions of amount and concentration of liquid intake. The numbers in parentheses at each point indicate the number of survivors. Data from rats which did not survive an entire 12-day period are excluded from the calculation of the mean for that block.

Analyses of variance were performed at each 12-day block. Initially, there were no weight differences among the nine groups. Over time, each group suffered a loss in weight, the magnitude of which was greatest among the $2 \%$ groups and least among the water $(0 \%)$ groups. Group 90-2 is not included in this generalization, since for the last three blocks it consisted of just two rats. On the last three blocks, the concentration effect was highly significant $[F(2,37)=10.72 ; F(2,35)=23.89 ; F(2,34)=$ $10.03 ; p<.001]$, while the effect of intake and the interaction of amount and concentration remained negligible. Individual comparisons, using the $\mathrm{L}^{2}$ statistic (Dixon \& Massey, 1969) to compensate for unequal Ns, showed that water $(0 \%)$ groups were significantly higher in weight than the $2 \%$ groups at each point. The $1 \%$ groups were always between these two values (with the 
Fig. 1. Mean body weights as functions of 12-day blocks. Numbers in parentheses are the number of survivors upon which each mean is based.

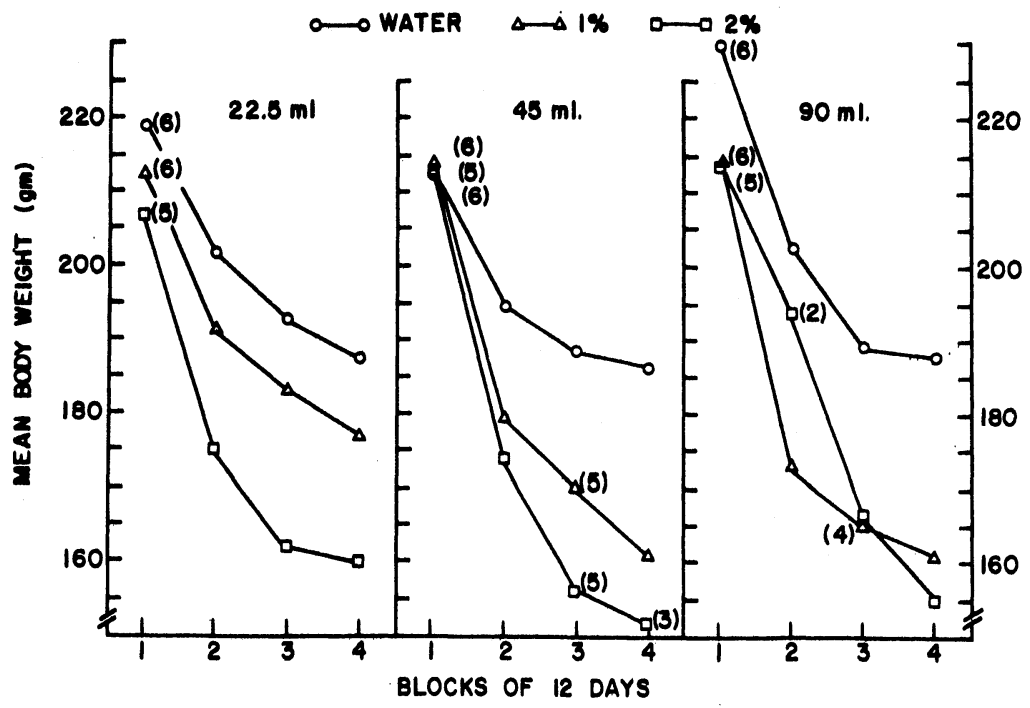

exception of comparisons involving 90-2), sometimes closer to $0 \%$ and sometimes closer to $2 \%$. To test for the effect of liquid consumption, per se, individual comparisons were calculated for Groups 22.5-2 vs 45-1 and for $45-2$ vs $90-1$. In each case, the amount of dissolved saccharin was held constant, while the volume drunk was doubled. These comparisons failed to reach significance on any of the four blocks, indicating no significant effect of amount of intake upon the body weight of groups which consumed the same absolute amount of saccharin. The possibility remains that a true effect of amount of intake has been masked by the systematic loss of $\mathrm{Ss}$ in the saccharin groups. Comparisons among the three $\mathrm{H}_{2} \mathrm{O}$ groups, however, also revealed no effect of amount consumed, which suggests that this is not the case. This finding further indicates that the additional variables of type of food (Noyes pellets vs Purina powder), schedule of food presentation, increased handling, etc., required by the polydipsia procedure had little biasing effect, since 45-0 and 90-0 remained nearly identical in body weight to 22.5-0 over a period of 48 days. Weight loss is not, therefore, brought about simply by ingesting an abnormal amount of liquid, since there is no difference in weight due to amount of intake in either the water or the saccharin groups. Consumption of saccharin, however, did result in weight loss relative to the water control regardless of whether the amount of intake was as small as $22.5 \mathrm{ml}$ or as large as $90 \mathrm{ml}$ per day. Furthermore, the magnitude of weight loss is a direct function of saccharin concentration and thus, within each level of intake, of absolute amount of saccharin consumed. These findings indicate that saccharin does have a definite physiological effect when administered under the present conditions.

In summary, saccharin can lead to loss of weight and death when ingested by food-deprived rats. The weight loss is directly related to saccharin concentration and absolute amount of daily saccharin intake, but it does not appear to be related to amount of intake per se.
Mortality, however, is complexly related to both amount and concentration of the ingested fluid.

Although the physiological reasons for the observed weight loss and death remain to be clarified, investigators should be mindful of the potentially harmful effects of this substance when employing it in behavioral studies.

\section{REFERENCES}

Beebe-Center, J. G., Black, P., Hoffman, A. C., \& Wade, M. Relative per diem consumption as a measure of preference in the rat. Journal of Comparative \& Physiological Psychology, $1948,41,239-251$

Bryan, G. T., Erturk, E., \& Yoshida, O. Production of mouse bladder carcinomas in mice by sodium saccharin. Science, $1970,68,1238-1240$.

Bunde, C. A., \& Lackey, R. W. Failure of oral saccharin to influence blood sugar. Proceedings for the Society of Experimental Biology \& Medicine, 1948, 68, 581-582.

Carlson, A. J., Eldridge, C. J., Martin, H. P., \& Foran, F. L. Studies on the physiological action of saccharin. Journal of Metabolic Research, 1923, 3, 451.

Dixon, W. J., \& Massey, F. J. Introduction to statistical analysis. New York: McGraw-Hill, 1969.

Falk, J. L. Production of polydipsia in rats by an intermittent food schedule. Science, 1961, 133, 195-196.

Ferster, C. G., \& Skinner, B. F. Schedules of reinforcement. New York: Appleton-Century-Crofts, 1957.

Folin, 0 . Preservatives and other chemicals in food: Their use and abuse. Cambridge: Harvard University Press, 1914

Haramaki, K. Ueber den Einfluss des Saccharins auf einige Funktionen des Verdaungs-apparats und der Nieren. Zeitschrift fur physikalisch und diaetetik Therapie, 1922, 26, 183-186.

Herter, C. A. The action of sodium benzoate and benzoic acid on the human organism. New York: Author, 1910.

Kun, E., \& Istvan, $H$. The influence of oral saccharin on blood sugar. Proceedings for the Society of Experimental Biology \& Medicine, 1947, 66, 175-177.

Strouthes, A. Long-range, two choice saccharin and water consumption in rats. Journal of Comparative \& Physiological Psychology, 1970, 73, 123-124.

Strouthes, A. Thirst and saccharin preference in rats. Physiology \& Behavior, 1971, 6, 287-292.

Strouthes, A. Saccharin drinking and mortality in rats. Physiology \& Behavior, 1973, 10, 781-791.

Valenstein, E.S. The significance of sodium in the preference for saccharin solutions. Psychonomic Science, 1966, 5, 341-342.

Valenstein, E. S., \& Weber, M. L. Potentiation of insulin coma by saccharin. Journal of Comparative \& Physiological Psychology, 1965, 60, 443-446.

Warren, R. P., \& Warren, R. M. Soluble saccharin preference: A nutritive basis for persistence. Nature, 1966, 210, 310-311.

(Received for publication January 21, 1974; revision received March $19,1974$. 